\title{
Study of a Bioclimatic Building in Wet Tropical Zone: Application of the Study of the Thermal Behavior of a Building in Cote D'ivoire
}

\author{
Tanoe Koffi Fernandez ${ }^{1}$, Gbaha Prosper ${ }^{2}$, N'guessan Rémi Kotchi ${ }^{2}$, Afféri Konan Jules ${ }^{1}$, \\ Gbossou Koudou Christophe ${ }^{1}$ \\ ${ }^{1}$ Institute for Renewable Energy (IREN), Nangui Abrogoua University, Abidjan, Ivory Coast \\ ${ }^{2}$ Department of Mechanical and Energy Engineering, Polytechnic Institute Felix Houphouet Boigny, Yamoussoukro, Ivory Coast
}

Email address:

tanoefer.iren@uni-na.ci (T. K. Fernandez)

\section{To cite this article:}

Tanoe Koffi Fernandez, Gbaha Prosper, N'guessan Rémi Kotchi, Afféri Konan Jules, Gbossou Koudou Christophe. Study of a Bioclimatic Building in Wet Tropical Zone: Application of the Study of the Thermal Behavior of a Building in Cote D'ivoire. International Journal of Sustainable and Green Energy. Vol. 7, No. 2, 2018, pp. 7-15. doi: 10.11648/j.ijrse.20180702.11

Received: August 21, 2018; Accepted: September 13, 2018; Published: October 11, 2018

\begin{abstract}
With population growth, the demand for housing continues to grow. Also, the energy crisis has shown the need for an energy efficiency policy in the building sector. Estimating the thermal behavior of a building is important in the energy efficiency approach. We present in this article the results concerning the climatic comfort in a building of the city of Abidjan. In this work, we study the thermal behavior of a building of architectural typology validated by the presidential construction program of 60,000 social housing units; our choice is also justified by the habit of Ivorians to live. This architectural model is implemented, with regard to the envelope, with a local material, available, offering the natural comfort: the clay brick. Today, earth material is gaining interest among architects and scientists because of its excellent thermal properties and abundant availability. Our experiments show, on the one hand, that in Côte d'Ivoire, to perform a simulation based on single-zone modelling or multizone modeling, from a low clay brick house, provides similar results; on the other hand, clay brick, when subjected to solar radiation, enhances overheating of the air in the building.
\end{abstract}

Keywords: Clay Brick, Walls, Thermal, Building

\section{Introduction}

Africa is the continent where population growth is fastest. It will by the way in the late 21th century, the second most populous continent after Asia according to the UN median scenario [1]. This demographic growth is intensifying the demand for housing. In Côte d'Ivoire, in this case, the housing deficit in urban areas is estimated at 600000 units; and half of this deficit is concentrated in Abidjan [2].

Indeed, most developing countries are undergoing an import of urban and architectural models [3]. New architectures integrating artificial climate control techniques at the expense of local models, based on careful and judicious choice of site and orientation, taking into account the sun, wind and humidity, better adapted to geoclimatic data specific to these regions [4].

Compressed clay brick is a material that reduces building consumption when seeking thermal comfort acceptable to its occupants $[5,6]$. This remarkable material plasticity and availability satisfying expectations as diverse as the response of the physical, environmental or financial, but also the aspirations of human nature, social and cultural [6].

\section{Materials and Methods}

Presentation of the study building

The geometry of the building is modelled in $3 \mathrm{D}$ using the Google Sketch Up software of the Google editor. This software is coupled with Open Studio to make it possible for Energy plus to read data (architectural and energy). We carried out a numerical study of the thermal behaviour of the building modelled in mono zone and multi zones. As for the single zone model, we consider the room's doors are opens. 


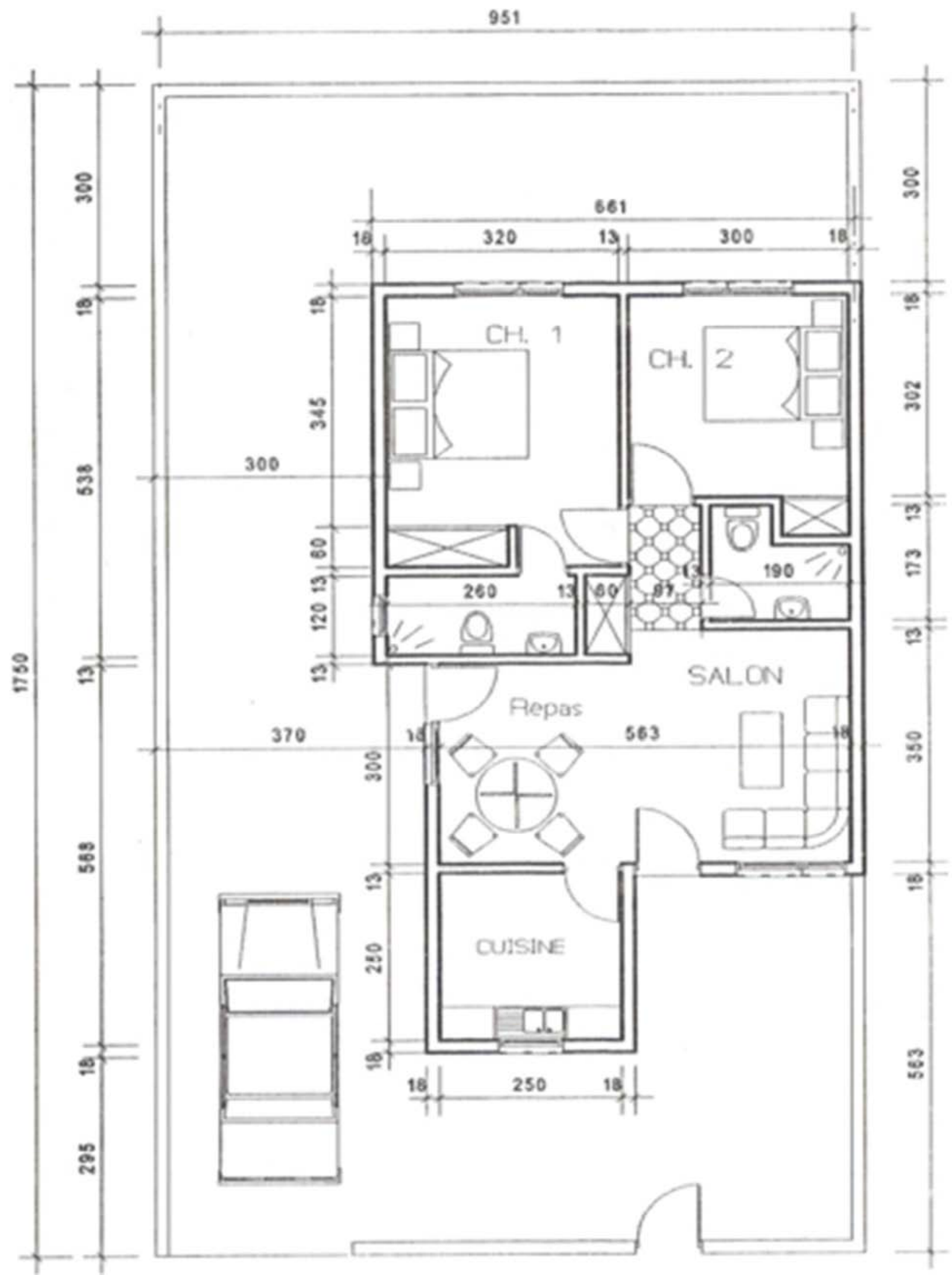

Figure 1. Mass plan of the study building. 


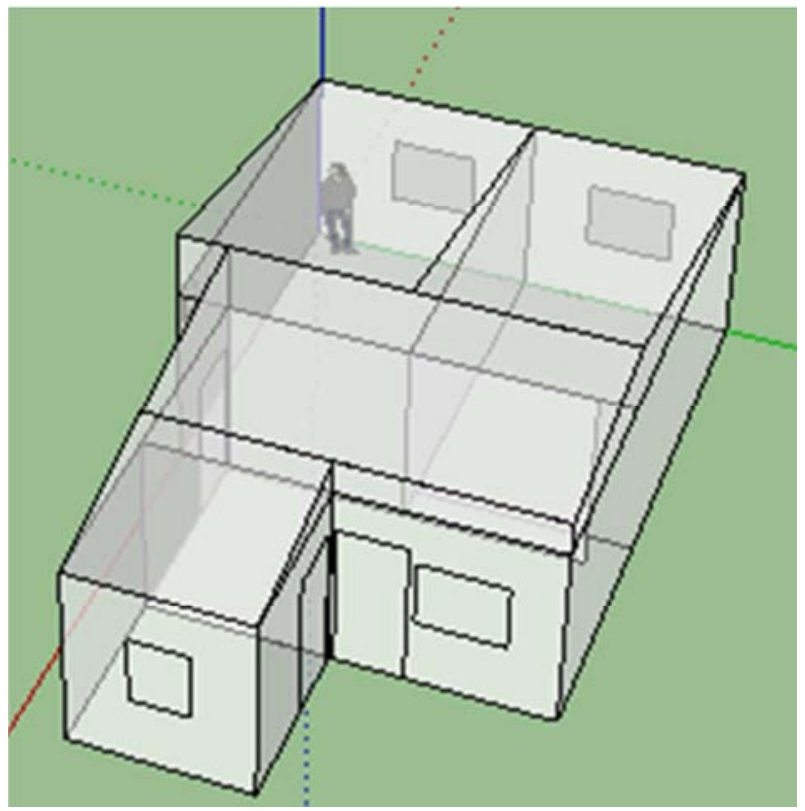

Figure 2. Sketch Up modelling of the study building.

Table 1. Constituent material envelope and their thermal characteristics [7].

\begin{tabular}{llllll}
\hline & Materials & conductivity $\left(\mathbf{W} / \mathbf{~ m}^{\circ} \mathbf{C}\right)$ & thickness $(\mathbf{m})$ & specific heat $\left(\mathbf{J} / \mathbf{k g}{ }^{\circ} \mathbf{C}\right)$ & $\mathbf{d e n s i t y ~}(\mathbf{k g} / \mathbf{~ m 3})$ \\
\hline \multirow{2}{*}{ INTERIOR FLOOR } & Concrete & 1.4 & 0.1 & 1700 & 2200 \\
& interior coating & 0.833 & 0,015 & 1000 & 1000 \\
OUTER WALLS & exterior coating & 0.833 & 0,015 & 1000 & 1000 \\
& outside clay brick & 0.9 & 0.15 & 3200 & 1000 \\
& interior coating & 0.833 & 0,015 & 1000 & 1000 \\
INNER WALLS & interior coating & 0.833 & 0,015 & 1000 & 1000 \\
& interior clay brick & 0.9 & 0.1 & 3200 & 1000 \\
ROOF & interior coating & 0.833 & 0,015 & 1000 & 7000 \\
& red lacquer & 50 & 0,002 & 450 & 7800 \\
CEILING & steel galva & 50 & 0,002 & 450 & 7800 \\
DOOR & sheet steel & 50 & 0.01 & 450 & 592 \\
\hline
\end{tabular}

From the architectural point of view, it is a typical residential building in Cote d'Ivoire. The construction model is based on architectures validated by the government as part of the construction of 60000 social housing units.

Table 2. Thermo physical Properties of Materials (Reagan and al., 1979).

\begin{tabular}{llll}
\hline Materials & Conductivity $\left(\mathbf{W} / \mathbf{~ m}^{\circ} \mathbf{C}\right)$ & Specific heat $\left(\mathbf{J} / \mathbf{k g}^{\circ} \mathbf{C}\right)$ & Density $\left(\mathbf{k g} / \mathbf{~ m}^{\mathbf{3}}\right)$ \\
\hline Galvanized steel sheet & 50 & 450 & 7800 \\
coating & 1,150 & 1000 & 1700 \\
Concrete & 1.4 & 1000 & 2200 \\
\hline
\end{tabular}

Table 3. Surface Properties of Materials (Kultulr and al., 2012).

\begin{tabular}{lll}
\hline & Infrared emissivity & Solar absorptivity \\
\hline Exterior plaster & 0.9 & 0.6 \\
Red lacquered roof & 0.8 & 0.6 \\
Galvanized steel & 0.2 & 0.6 \\
White interior plaster & 0.9 & 0.2 \\
\hline
\end{tabular}

Our building is built in clay brick with $0 \%$ cement content. The thermal characteristics of the model's building materials are indicated by the thermo-physical properties and surface properties (Table 2 and 3) as stated in literature [8]. The albedo of the surrounding soil is 0.2 [9].

The main entrance of the building is oriented North. The walls are made of clay brick $0.15 \mathrm{~m}$ thick and $0.10 \mathrm{~m}$ thick respectively for the exterior and interior and are covered on the outside and inside with a thickness of cement coating. $0.015 \mathrm{~m}$. The partitions have the same composition as the wall. The floor consists of a layer of laterite surmounted by a layer of concrete as a screed with a smooth finish. The vaulted double slope roof is made of galvanized sheet steel with filler. The roof is not ventilated. The outer face is prelacquered with a colour between red and orange. The total area of the walls is estimated at $115.05 \mathrm{~m}^{2}$, of which 26.56 $\mathrm{m}^{2}$ are facing north, $35.57 \mathrm{~m}^{2}$ are oriented full east, $17.36 \mathrm{~m}^{2}$ are facing south and $35.57 \mathrm{~m}^{2}$ are facing west. The total areas of windows are $4.56 \mathrm{~m} 2$ of which $2 \mathrm{~m}^{2}$ on the north side i.e. 
$7.53 \%$ of the surface of this wall; $0.16 \mathrm{~m}^{2}$ On the east face of which $0.45 \%$ of the surface of this wall and $2.4 \mathrm{~m}^{2}$ on the south face is $13.82 \%$ of the surface of this wall. The building has an interior volume of $297.3 \mathrm{~m}^{3}$.

\subsection{Meteorological Data}

The study is carried out for the climate of the Ivory Coast and meteorological data are derived from the meteonorm database [10] and in the TRY format with an epw extension. They are provided with .ddy files (day year) which regroup the statistical analysis of the hourly data and contains the typical days of each seasons. These design days are calculated according to ASHRAE HOF design condition tables.

The coordinates of the registration station of AbidjanAirport are as follows:

\begin{tabular}{r|r} 
Latitude [deg] & 5.25 \\
\hline Longitude [deg] & -3.9 \\
\hline Elevation [m] & 8.00
\end{tabular}

\subsection{The Tropical Humid zone: Presentation and Delimitation}

This zone is defined as the part of the Earth's surface that receives the Sun's rays twice a year and it is perpendicular at noon when the sun passes to the zenith. It extends in total to $46 \circ 55$ 'of latitude, symmetrically on both sides of the equator. The air temperature varies between 27 and $32^{\circ} \mathrm{C}$ during the day and between 21 and $27^{\circ} \mathrm{C}$ at night. Relative humidity is around $75 \%$ all year round. Solar radiation is important, although it is partially mitigated by cloud cover; the wind is weak; precipitation is important [11]. Also, precipitation and winds are the main determinant of the seasons [12]. Seasonal zonal balancing means that a large part of the tropical regions are alternately subjected to arid and rainy season of months. This vast area actually embraces quite diverse natural environments that share only their high temperature throughout the year (see Figure 2).

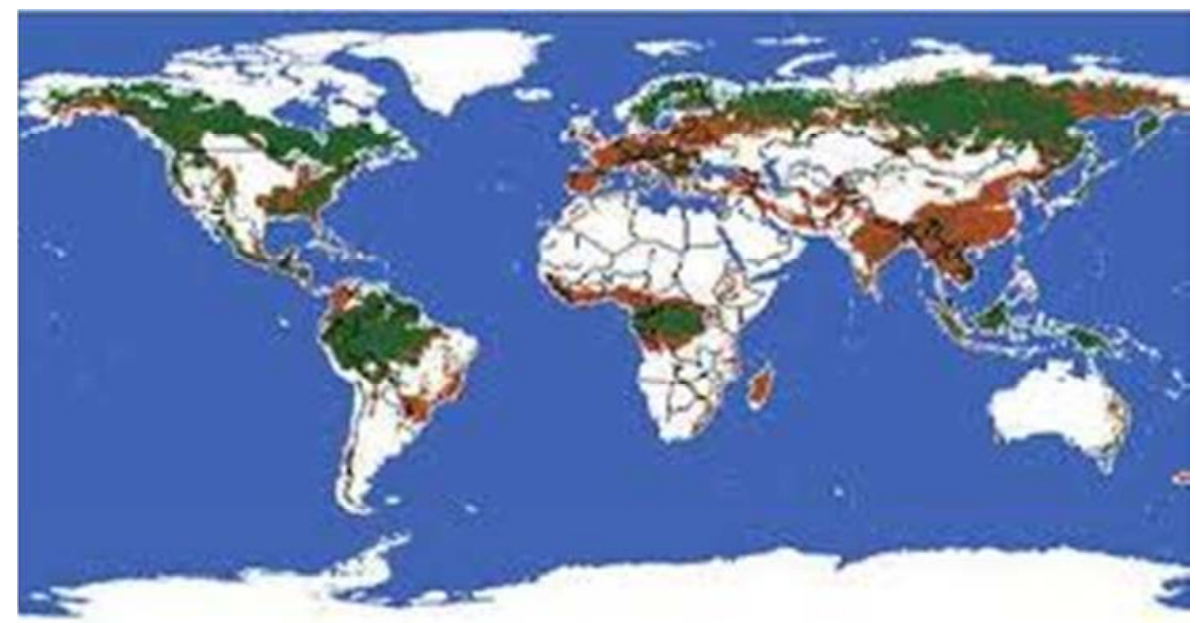

Figure 3. World map with tropical wetland represented in green and orange according to the abundance of vegetation (by François catzetflis).

The limits of comfort or thermal discomfort are difficult to define in a precise way. However, comfort limits in the form of diagrams and thermal indices were determined in controllable laboratory environments, to facilitate their use by the researcher (table 4).
A relatively high air temperature can thus be made bearable by increasing the air velocity, while conversely the effect of a high air velocity can be compensated in a zone limited by a temperature rise.

Table 4. Summer comfort threshold temperature values, in degrees Celsius [13].

\begin{tabular}{|c|c|c|c|c|c|c|c|c|}
\hline \multicolumn{9}{|c|}{$1 /$ Choice of the temperature threshold $\left(\mathrm{V}_{\text {air }}=0 \mathrm{~m} / \mathrm{s}\right)$ according to the external humidity } \\
\hline $\mathrm{T}_{\mathrm{e}} / \mathrm{HR}$ & $<45 \%$ & $45 \%-60 \%$ & $>60 \%$ & \multirow{2}{*}{\multicolumn{5}{|c|}{ * - for the hottest month }} \\
\hline$>30^{\circ} \mathrm{C}$ & $29^{\circ} \mathrm{C}$ & $27^{\circ} \mathrm{C}$ & $27^{\circ} \mathrm{C}$ & & & & & \\
\hline $30^{\circ} \mathrm{C}>\mathrm{T}_{\mathrm{e}}>28^{\circ} \mathrm{C}$ & - & 27 & $27^{\circ} \mathrm{C}$ & \multirow{2}{*}{\multicolumn{5}{|c|}{$\begin{array}{l}\text { Te - average outdoor temperature of the maximum } \\
\text { HR- the average outdoor relative humidity of the minimum }\end{array}$}} \\
\hline$<28^{\circ} \mathrm{C}$ & - & $26^{\circ} \mathrm{C}$ & $26^{\circ} \mathrm{C}$ & & & & & \\
\hline \multicolumn{9}{|c|}{2 / Correction of previous thresholds according to the expected air speed : } \\
\hline \multicolumn{9}{|c|}{ Comfort threshold temperature $\left(\mathrm{T}_{\text {thresholdconf }}\right)$} \\
\hline 0 & 0.06 & 0.13 & 0.50 & 0.80 & 1.00 & 1.50 & 2.00 & 3.00 \\
\hline 26 & 26 & 27 & 29 & 30 & 30 & 31 & 31 & 32 \\
\hline 27 & 27 & 28 & 30 & 31 & 31 & 32 & 32 & 33 \\
\hline 28 & 28 & 29 & 31 & 32 & 32 & 33 & 33 & 34 \\
\hline 29 & 29 & 30 & 32 & 33 & 33 & 34 & 34 & 35 \\
\hline
\end{tabular}




\subsection{Presentation of Study Tools: Software}

Google Sketch Up: Google Sketch Up is a particularly effective software for geometric modelling in 3 dimensions of buildings. It is made freely available by the Google publisher. It allows the plug in Open Studio to provide the architectural model with thermal properties.

Open Studio: Thanks to Open Studio, Energy plus can read geometric data, created from Google Sketch Up, in order to perform thermal calculations selected in the Run Manager section. This allows the user to access the model, run simulation tests, and examine the data. It currently supports Energy Plus simulations.

Energy plus: Thermal simulation in the sense of Energy plus is the interaction of an architectural building model, a climate model and a building use model. This last model will not be taken into account because we consider our building in free evolution that is without energy system. Therefore, the main assumptions concern the building envelope, the aeraulic, and the numerical model of resolution. Also, the method of transfer functions "CTFs" was used for the resolution of heat transfer equations in the walls and at the level of the roof. For convective exchange, we considered the ASHRAE proposed Thermal Analysis Research Program (TARP) correlation for interior surfaces and the DOE-2 correlation for exterior surfaces. Moreover, the model of the sky is based on the empirical model described by Perez [14].

\subsection{Calculation Method of Heat Transfer Through the Envelope: CONDUCTION - CTF}

The most basic solution is the equation that links the heat flux passing through a surface to the temperature variation on both sides of a surface element as shown in equation:

$$
\mathrm{q}_{\mathrm{ko}}^{\mathrm{n}}(\mathrm{t})=\sum_{\mathrm{j}=0}^{\infty} \mathrm{X}_{\mathrm{j}} \mathrm{T}_{\mathrm{o}, \mathrm{t}-\mathrm{j} \delta} \sum_{\mathrm{j}=0}^{\infty} \mathrm{Y}_{\mathrm{j}} \mathrm{T}_{\mathrm{i}, \mathrm{t}-\mathrm{j} \delta}
$$

Where « $\mathrm{q}_{\mathrm{ko}}^{\mathrm{n}}$ » is the heat flux, « $\mathrm{T} »$ is the temperature, « $\mathrm{i}$ $»$ is the inside of the building element, « $\mathrm{O} »$ is the outside of the building element, « $\mathrm{t} »$ is the current time step, and « $\mathrm{X} »$ and $« \mathrm{Y} »$ are the answer factors.

The solution contains elements called conduction transfer functions (CTFs). The basic form of a conduction transfer function solution is represented by the following equation:

$$
\begin{aligned}
& \mathrm{q}_{\mathrm{ki}}^{\prime \prime}(\mathrm{t})=-\mathrm{Z}_{\mathrm{o}} \mathrm{T}_{\mathrm{i}, \mathrm{t}}-\sum_{\mathrm{j}=1}^{\mathrm{nz}} \mathrm{Z}_{\mathrm{j}} \mathrm{T}_{\mathrm{i}, \mathrm{t}-\mathrm{j} \delta}+\mathrm{Y}_{\mathrm{o}} \mathrm{T}_{\mathrm{o}, \mathrm{t}}+\sum_{\mathrm{j}=1}^{\mathrm{nz}} \mathrm{Y}_{\mathrm{j}} \mathrm{T}_{\mathrm{o}, \mathrm{t}-\mathrm{j} \delta}+\sum_{\mathrm{j}=1}^{\mathrm{nq}} \theta_{\mathrm{j}} \mathrm{q}_{\mathrm{ki}, \mathrm{t}-\mathrm{j} \delta}^{\mathrm{n}} \\
& \mathrm{q}_{\mathrm{ko}}^{\prime \prime}(\mathrm{t})=-\mathrm{Y}_{\mathrm{o}} \mathrm{T}_{\mathrm{i}, \mathrm{t}}-\sum_{\mathrm{j}=1}^{\mathrm{nz}} \mathrm{Y}_{\mathrm{j}} \mathrm{T}_{\mathrm{i}, \mathrm{t}-\mathrm{j} \delta}+\mathrm{Y}_{\mathrm{o}} \mathrm{T}_{\mathrm{o}, \mathrm{t}}+\sum_{\mathrm{j}=1}^{\mathrm{nz}} \mathrm{Y}_{\mathrm{j}} \mathrm{T}_{\mathrm{o}, \mathrm{t}-\mathrm{j} \delta}+\sum_{\mathrm{j}=1}^{\mathrm{nq}} \theta_{\mathrm{j}} \mathrm{q}_{\mathrm{ko}, \mathrm{t}-\mathrm{j} \delta}^{\mathrm{n}}
\end{aligned}
$$

For the external heat flux $\left(q^{\prime \prime}=\mathrm{q} / \mathrm{A}\right)$

Where

$X_{j}$ External CTF coefficient, $j=0,1, \ldots n z$.

$\mathrm{Y}_{\mathrm{J}} \mathrm{CTF}$ coefficient across the wall, $\mathrm{j}=0,1, \ldots \mathrm{nz}$.

$\mathrm{Z}_{\mathrm{J}}$ Internal CTF coefficient, $\mathrm{j}=0,1, \ldots \mathrm{nz}$.

$\theta_{\varphi}$ CTF flux coefficient, $j=1.2, \ldots$ nq.

$\mathrm{T}_{\mathrm{i}}$ Temperature of the inside face

$\mathrm{T}_{\mathrm{o}}$ Temperature of the outside face

$\mathrm{q}_{\mathrm{ko}}^{\mathrm{n}}$ Heat flow by conduction on the outer face

$\mathrm{q}^{\mathrm{n}}$ Heat flow by conduction on the inside

\subsection{Convection Calculation Method: TARP}

Walton has developed a mathematical model to take into account convection. This model is called TARP, or Thermal Analysis Research Program [15]. In this model, the Outer convection is divided into forced and natural components [16] and the total convection coefficient is the sum of these two components:

$$
\mathrm{h}_{\mathrm{c}}=\mathrm{h}_{\mathrm{f}}+\mathrm{h}_{\mathrm{n}}
$$

The forced convection component is based on the correlation of Sparrow, Ramsey and Mass [17] (Sparrow et al., 1979).

$$
\mathrm{h}_{\mathrm{f}}=2.537 \mathrm{~W}_{\mathrm{f}} \mathrm{R}_{\mathrm{f}}\left(\frac{\mathrm{PV}_{\mathrm{z}}}{\mathrm{A}}\right)^{1 / 2}
$$

Where $\mathrm{W}_{\mathrm{f}}=1.0$ For surface exposed to the wind Where $\mathrm{W}_{\mathrm{f}}=0.5$ For non-windy surface

The surface roughness coefficient $R_{f}$ is based on the ASHRAE graph of surface conductance [18] (ASHRAE, 1981).

\section{Results and Discussion}

An annual average hourly temperature analysis indicates that $51 \%$ of the readings is between $21^{\circ} \mathrm{C}$ and $27^{\circ} \mathrm{C}$ and $48 \%$ between $27^{\circ} \mathrm{C}$ and $38^{\circ} \mathrm{C}$ 


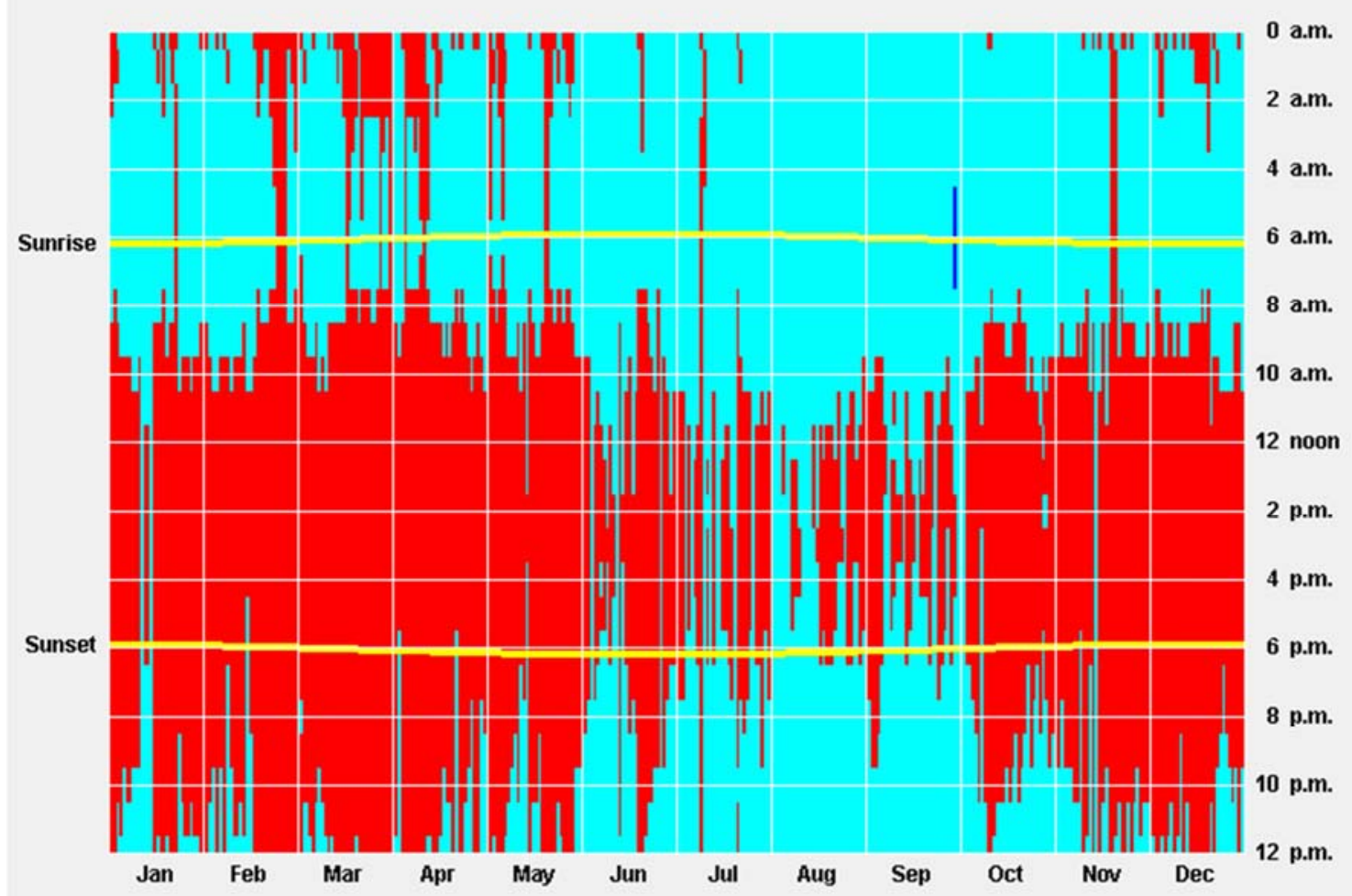

Figure 4. Hourly distribution of annual moisture (climate consultant).

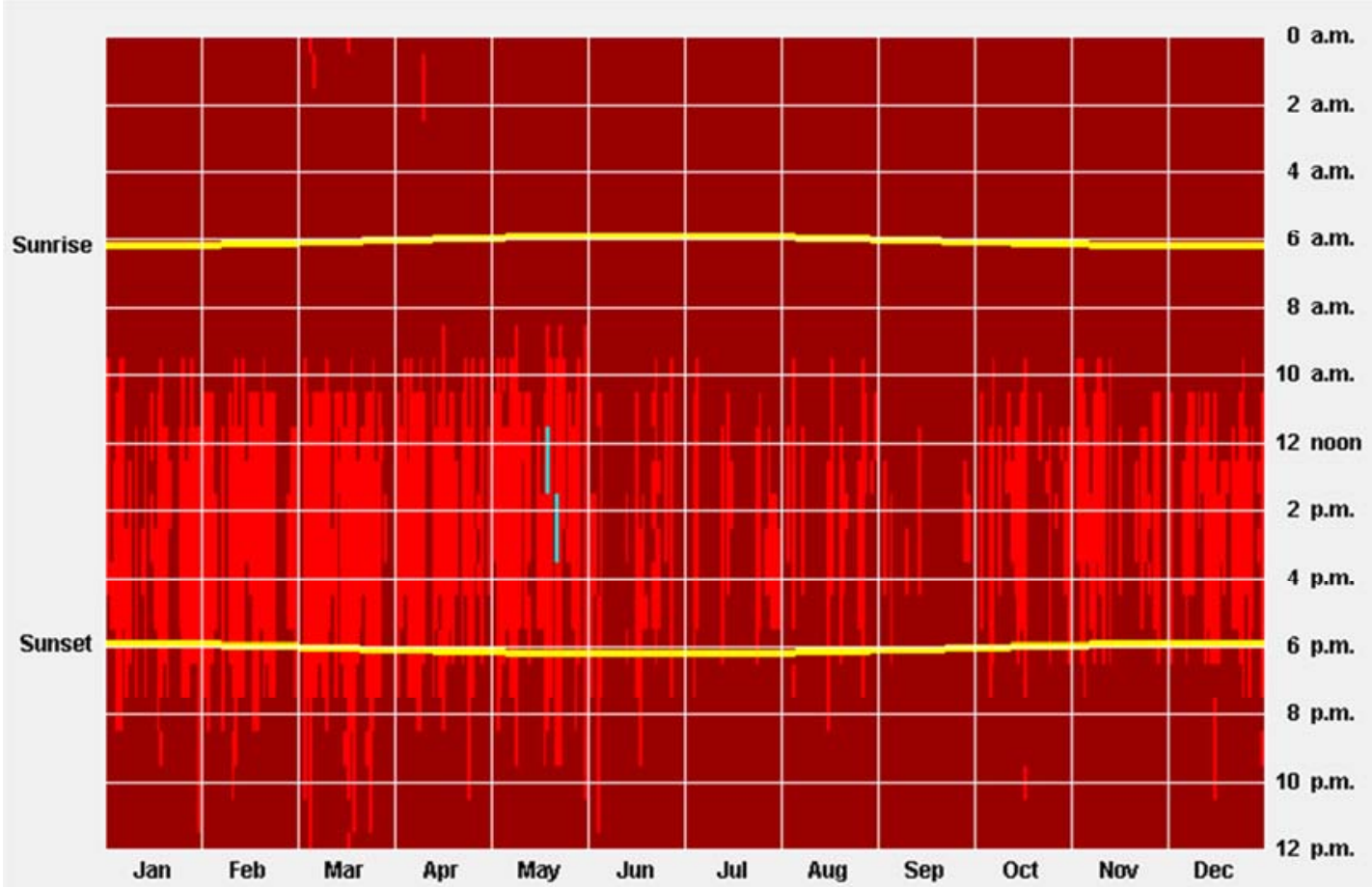

Figure 5. Hourly distribution of annual temperature (climate consultant).

An annual average hourly humidity analysis indicates that we have $18 \%$ of readings that are between $60 \% \mathrm{RH}$ and $80 \%$ RH and $82 \%$ above $80 \%$ RH

Orientation and the winds

We represent the wind rose that defines for each direction:
(1) In yellow the proportion of hours of the year according to each direction.

(2) in blue and red respectively temperatures between $21^{\circ} \mathrm{C}$ and $27^{\circ} \mathrm{C}$ and between $27^{\circ} \mathrm{C}$ and $38^{\circ} \mathrm{C}$

(3) -in green, we have relative humidity 
(4) In orange colour (for the different gradients) the intensity of the winds

a the light orange represents the minimum intensity, b Orange represents the average of the wind intensities

c Dark orange represents maximum intensity

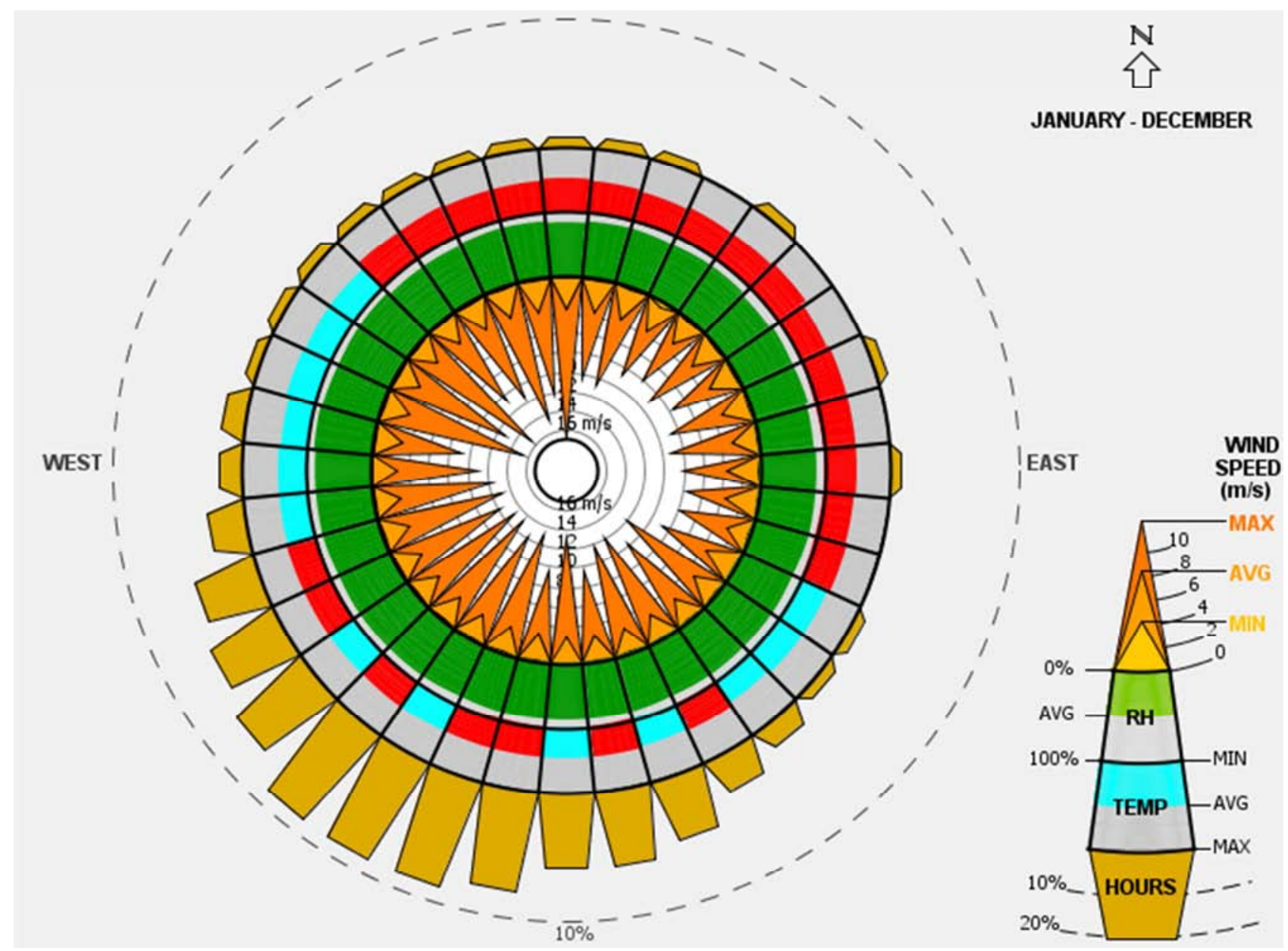

Figure 6. Annual wind (climate consultant)

We observe that:

(1) The direction of the prevailing winds is south -west

(2) The average wind intensity is $2 \mathrm{~m} / \mathrm{s}$ for all directions

(3) Southeast, south, southwest, and northwest directions record the highest wind intensities ranging from $12 \mathrm{~m} /$ $\mathrm{s}$ to $16 \mathrm{~m} / \mathrm{s}$

(4) South-west temperatures are colder than temperatures, north and northeast

According to Figure 5, 28\% of the winds has a speed lower than $2 \mathrm{~m} / \mathrm{s}, 20 \%$ has a speed between 2 and $3 \mathrm{~m} / \mathrm{s}, 33 \%$ of the winds has a of speed between 3 and $5 \mathrm{~m} / \mathrm{s}, 18 \%$ of the winds has a speed between 5 and $9 \mathrm{~m} / \mathrm{s}$ and $2 \%$ a speed greater than $9 \mathrm{~m} / \mathrm{s}$.

Thus $70 \%$ of the winds do not exceed the speed of $5 \mathrm{~m} / \mathrm{s}$ and the monthly average of $2.2 \mathrm{~m} / \mathrm{s}$. In another study, Arens concluded that the comfort zone can be expanded to $31{ }^{\circ} \mathrm{C}$ with an air velocity of $1 \mathrm{~m} / \mathrm{s}$ or more [19]. The analysis of the monthly distribution of temperature and relative humidity of the city of Abidjan indicates that most of the year is outside the comfort zone.

Our work aims to characterize the sensation of thermal comfort that an occupant will feel in our building. The operating air temperature of the building, as a bioclimatic index, is used to thermally characterize comfort. To take into account the seasonal variability, we carried out our study over a period of one year thanks to the Energy plus calculation program.

Recall that the standard minimum and maximum comfort temperatures are respectively $24.2^{\circ} \mathrm{C}$ and $27^{\circ} \mathrm{C}$ respectively. Also, the soil temperature that was not provided by the meteorological file, we took a recommendation according to ASHRAE specification of the soil's temperature equal to $24.77^{\circ} \mathrm{C}$.

Figure 6 shows the annual changes in the operational indoor temperature of the building for single-zone and multizone configurations in order to analyse the impact of the choice of one or the other of these two configurations.

In addition, the thermal comfort threshold temperatures of a building in a tropical humid zone are shown in order to have a basis for analysis.

In the multi zone configuration, the roof has a high temperature of more than $2^{\circ} \mathrm{C}$ compared to other areas that are, by the way, very similar.

Also, the results for a mono zone dynamic thermal 
simulation gives a difference in building and exterior temperatures ranging from $2^{\circ} \mathrm{C}$ to $5^{\circ} \mathrm{C}$. The work done by Kabore [20], for the city of Ouagadougou in Burkina Faso, shows that for a building of different architecture but with the same materials as our case study of temperature differences of the order of $2^{\circ} \mathrm{C}$ to $5^{\circ} \mathrm{C}$ for the period from 14 to 23 February 2014.

However, comfort is reached only 11 days in the year while outdoor weather conditions give 191 days. The envelope of our clay brick building is, therefore, a source of overheating of the air : it promotes a greenhouse effect.
These 11 days of comfort during all the time of the year, which are :

(1) 1 day in the period of very high temperature that is January 15

(2) 10 days in the relatively low temperature period i.e. July 12, 04, 06, 07, 11, 12, 13.14 August, 08 and 17 September.

Finally, the presence of sun is a source of discomfort in tropical areas. This can also be seen in the work of Givoni, Ahmed khan, Sako, and Assimakopoulou [21, 22, 23].

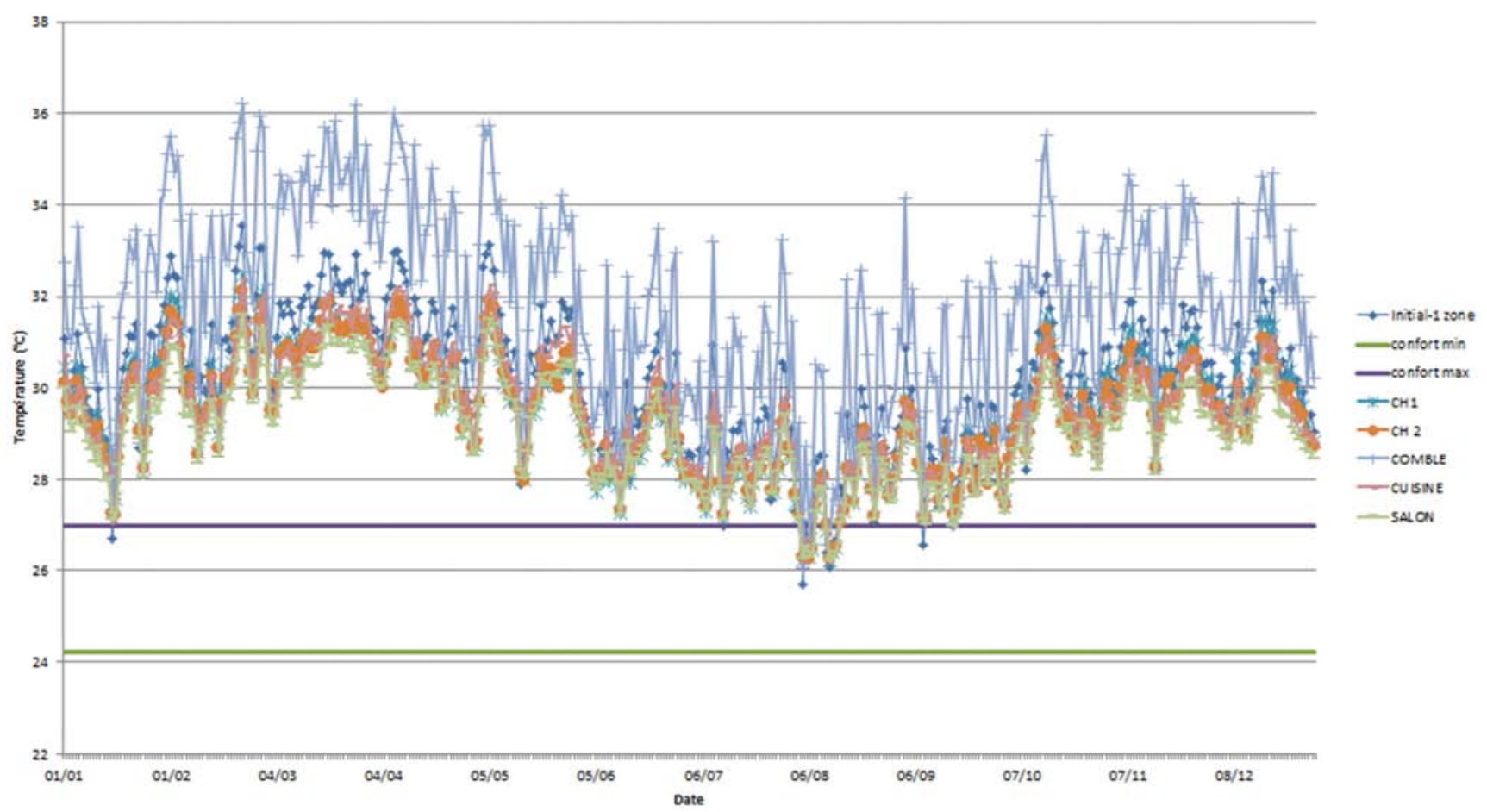

Figure 7. Annual evolution of the operating temperature of the indoor air of the building for single-zone and multi-zone configurations.

\section{Conclusion}

Our research was on a residential building of an architectural typology largely widespread and adopted by the Ivorian government within the framework of the presidential project for the construction of 60000 social housing. The implementation of the walls was done in clay brick, in our work of numerical study of the thermal behaviour. In addition, these simulations have been done with the Google Sketch UP, Open studio and Energy plus software. We retain that for a low house in Ivory Coast, mono zone model as multi zone model can be used to characterize thermal behaviour for bulding. Also, clay brick, although better at cinderblock can help to create overheating of the building air at the expense of comfort. New energy and environmental concerns regarding thermal comfort in buildings require precise knowledge of temperatures and heat transfer through the walls. In Ivory Coast, solar radiation contributes to overheating for buildings. Thus the design of the walls of a bioclimatic building requires protection.

\section{References}

[1] P. Motel Combes, E. Kéré. 2015. Energy Challenges in SubSaharan Africa, editions of the Africa Days.

[2] The World Bank. 2017. Conference, seminar on buildings and eco-energy districts in Côte d'Ivoire.

[3] Christelle, Robin. 1999. "Anthropology of the architectural and urban space - ecology and development" in symposium act: architecture and the Algerian city facing the challenges of the 21st century, international seminar Biskra pp 231-232.

[4] Ramos AF, Mendes da silva J., Adapting portuguese architecture to form African colonies climate conditions, International Journal for Housing Science and Applications, 2017.

[5] F. Ouattara and A. Memeledje. 2008. two-dimensional simulation of a round box in geobeton: Obtaining thermal comfort by choice of materials from the envelope, science journal, Vol 8. 
[6] M P Meukam. 2004. Valorisation of stabilized earth bricks for the thermal insulation of buildings, PhD Thesis, University of Cergy-Pontoise, University of Yaoundé I, Yaoundé.

[7] Moro Olivier BOFFOUE, Kou Kouadou, Kouakou. 2015. Influence of the cement content on the thermomechanical properties of compressed and stabilized clay blocks , Africa science.

[8] Kultulr, Sinem, and Nil Tulrkeri. 2012. "Assessment of long term solar reflectance performance of roof coverings measured in laboratory and infield."

[9] OFFERLE, B., P. JONSSON, I. ELIASSON, and CSB GRIMMOND. 2005. "Urban Modification of the Surface Energy Balance in the West African Sahel: Ouagadougou, Burkina Faso." JOURNAL OF CLIMATE 18: 3983-3995

[10] Meteonorm 7. 2013. Global Meteorological Database. Tech. rep ... Genossenschaft METEOTEST.

[11] LIEBARD, A ET DE HERDE, A. 2006. Traité d'architecture et d'urbanisme bioclimatiques.Ed Le moniteur, Paris.

[12] Rosenlund, Hans (2000). Climatic Design Of Buildings Using Passive Techniques. BuildingIssues, Vol . 10, No. 1 , P : 3- 26

[13] CSTB. 1992. Guide to natural climate control of tropical climate habitat wet, volume 1, CSTB, Paris.

[14] Perez, R., Pierre I., Seals R., Michalsky J., and Stewart R. 1990. "Modeling daylight availability and irradiance components of direct and global irradiance." Solar Energy 44 (5): 271-289.

[15] Walton, G. N. 1983. Thermal Analysis Research Program Reference Manual. NBSSIR 83-2655. National Bureau of Standards.
[16] Walton, GN 1981. Passive Solar Extension of the Building Loads Analysis and System Thermodynamics (BLAST) Program, Technical Report, US Army Construction Engineering Research Laboratory, Champaign, IL.

[17] Sparrow, E. M., J. W. Ramsey, and E. A. Mass. 1979. Effect of Finite Width on Heat Transferand Fluid Flow about an Inclined Rectangular Plate. Journal of Heat Transfer, Vol. 101, p.204.

[18] Ashrae. 1981. ASHRAE Handbook - Fundamentals, Atlanta: American Society of Heating, Refrigerating, and AirConditioning Engineers, Inc.

[19] Arens E., Xu T., Miura K., et al. A study of occupant cooling by personnally controlled air movement. Energy and buildings, 1998, vol. 27, No. 1, pp. 45-59.

[20] Madi Kabore. 2015. Challenges of simulation for the study of energy performance of buildings in sub-Saharan Africa, thesis.

[21] Givoni, B. 1998. Climate Considerations in Building and Urban Design, Wiley \& sounds, New York, 464 p.H. Ezbakh, S. Bousad, A. Bakkour El, T. Ajzoul and A. El Bouardi. 2001 Thermal study of the cement stabilized earth used in construction in northern Morocco.

[22] MK Sako, Prosper GBAHA, Y N'Guessan, MK Kouadio. 2006. Bioclimatic design of the habitat in tropical climate: case of Ivory Coast, Global Journal of Pure and Applied Sciences.

[23] MN Assimakopoulou. 2004. Development and evaluation of control systems and strategies of electrochromic glazing for building applications, $\mathrm{PhD}$ in Civil Engineering, National Institute of Applied Sciences of Lyon. 